\title{
Determination of Total Phenolic Compounds, Antioxidant Activity and Ferulic Acid in Extracts of Sugar Beet Pulp
}

\author{
Şeker Pancarı Küspesi Özütünde Toplam Fenolik Bileşikler, \\ Antioksidant Aktivite ve Ferulik Asit Tayini
}

Research Article

Aazam Aarabi', Masoud Honarvar' ${ }^{*}$, Maryam Mizani', Hossein Faghihian²

'Department of Food Science and Technology, Tehran Science and Research Branch, Islamic Azad University, Tehran, Iran. 2Department of Chemistry, Shahreza Branch, Islamic Azad University, Shahreza, Iran.

\section{A B S TR ACT}

\begin{abstract}
$\mathrm{n}$ the resent research, two extracts (methanol and $\left.\mathrm{NaOH}\left(0.5 \mathrm{molL}^{-1}\right)\right)$ were analyzed for the total phenolic contents (TPC), ferulic acid concentration and antioxidant activity. Results revealed that significant differences were found in TPC among different extracts and alkaline extracts contained higher amounts of polyphenols than methanolic extract. The ferulic acid concentration in the solvent and alkaline liquor varied according to extraction time and there were no significant differences between the ferulic acid concentration for all methanolic treatments. Antioxidant capacity for extracts were shown that the significant differences were found at a level of $(p<0.05)$ between all extracts and correlation coefficient $\left(r^{2}=0.82\right)$ showed that total phenolic content was responsible for antiradical efficiency in sugar beet pulp extracts. Our results strongly suggest sugar beet pulp extracts can be promising sources of potential antioxidants that can be used as additive in food industry.
\end{abstract}

\section{Key Words}

Antioxidant activity, phenolic compounds, ferulic acid, sugar beet pulp.

\section{ÖZET}

$\mathbf{Q}$ u araştırmada iki özütün [metanol ve $\mathrm{NaOH}\left(0.5 \mathrm{molL}^{-1}\right)$ ], toplam fenolik içeriği, ferulik asit derişimi ve Bantioksidan aktivitesi analiz edildi. Sonuçlarda TFi de fenolik miktarın metanolik miktara göre daha fazla olduğu alkalin ve farklı ekstraklar arasında önemli farklılıklar olduğu görüldü. Solvent ve alkali likörlerindeki ferulik asit derişimleri ekstraksiyon zamanına göre çeşitlendirildiğinde, tüm metanolik tedavilerde ferulik asit konsantrasyonları arasında önemli bir fark olmadığı gözlendi. Ekstratlar için antioksidan kapasite, şeker pancarı küspesi ekstraktında antiradikal etki için sorumlu toplam fenolik içerik gösteren korelasyon sayısı ( $r^{2}$ $=0.82)$ ve tüm ekstratlar arasında $(p<0.05)$ seviyesinde bulunan önemli farklılıklarla gösterildi. Sonuçlarımız ışı̆̆ında şeker pancarı küspesi ekstraklarının gıda endüstirisinde katkı olarak kullanılabileceği ve potansiyel bir antioksidan kaynağı olabilecği görüldü.

\section{Anahtar Kelimeler}

Antioksidan aktivite, fenolik bileşikler, ferulik asit, şeker pancarı küspesi.

Article History: Received: Oct 22, 2015; Revised: Nov 27, 2015; Accepted: Nov 27, 2015; Available Online: Dec $30,2015$.

Dol: 10.15671/HJBC.20164315982

Correspondence to: M. Honarvar, Department of Food Science and Technology, Islamic Azad University, Tehran, Iran. 


\section{INTRODUCTION}

henolic compounds which are secondary metabolites in plants are one of the most widely occurring groups of phytochemicals that exhibit antiallergenic, antimicrobial, antiartherogenic, antithrombotic, anti-inflammatory, vasodilatory and cardio protective effects $[1,2]$.

Phenolics are antioxidants with redox properties, which allow them to act as reducing agents, hydrogen donators, and singlet oxygen quenchers. They have also metal chelation properties. Recently there has been an upsurge of interest in the therapeutic potentials of medicinal plants as antioxidants in reducing such free radical induced tissue injury [3]. Extraction of major phenolic compounds from agricultural crop residues is important for the development of value added products from renewable byproducts [4]. One of these potential sources is sugar beet pulp (SBP), a main by-product of sugar beet industries. It is a valuable by-product, but at present it is only used as animal feed. Ferulic acid (FA) is an ubiquitous phenolic plant constituent that exhibits a wide range of therapeutic effects against cancer, diabetes, cardiovascular and shows potential commercial application in food and cosmetic industries [5].

Currently, FA is widely used in food as a preservative due to its antioxidant, antimicrobial actions and as a cross-linking agent to gel formation [6].

Based on the traditional claims surrounding sugar beet and the lack of scientific studies on ferulic acid extraction, the objective of this study was to evaluate the ferulic acid concentration and also elucidate total phenolic content and antioxidant activity through direct free radical scavenging methods of sugar beet pulp extracts.

\section{MATERIAL AND METHODS Materials}

Sugar beet pulp (SBP) was provided by Isfahan Sugar Factory (Isfahan, Iran). Trans-ferulic acid as external standard and ABTS(2,2'-azinobis(3-ethylbenzthiazoline-6-sulphonicacid)) from Aldrich Chemical Co. (Milwaukes, WI, USA), Sodium Hydroxide, ethanol, methanol, $\mathrm{KBr}$, Gallic acid, ethyl acetate and Folin-Ciocalteu reagent were obtained from Merck Chemical Company.

\section{Instrumentation}

Panasonic MX-J120-P mill type laboratory. HPLC (Agilent Technologies), equipped with a Zorbax C18 column (length $150 \mathrm{~mm} \times 4.6 \mathrm{~mm}$ dpi. $5 \mu \mathrm{m}$ particle size, $300 \AA$ pore size, Agilent Technologies 1200 series, USA) and coupled online with a UV/ Vis Agilent Technologies detector. Perkin Elmer spectrum 65 FT-IR spectrometer (USA). PTFE syring-driven filters $(0.22 \mu \mathrm{m}$ pore size) were provided by Biofil (Germany).

\section{Sample Preparation}

Sugar beet pulp (SBP) was soaked in water for 3 hours to extract sugar residues, then it was dried in vacuum oven at $40^{\circ} \mathrm{C}$ for $12 \mathrm{~h}$ and ground in a laboratory mill. The powdered sample was passed through a set of sieves, and the fraction retained on the sieve with mesh size $0.9 \mathrm{~mm}$ was taken for further investigations [7].

\section{Extraction Method}

\section{Extraction with Methanol}

Methanol was the most commonly used extraction solvent in the assay of phenolic compounds herbs in literatures [3]. An important factor for the choice of an solvent is its polarity and ferulic acid is a polar compound and methanol has a protective role.

In this study, $5 \mathrm{~g}$ of SBP was mixed in $100 \mathrm{ml}$ of methanol solution $(99 \% \mathrm{v} / \mathrm{v})$ and the extraction of ferulic acid was performed by reflux for 2,6 and 12 hours at $60^{\circ} \mathrm{C}$ temperature. Then, the $\mathrm{pH}$ of metalonic extracts was adjusted to 2.0, with $\mathrm{HCl} 6 \mathrm{M}$ for lignin precipitation [8]. The mixture was filtered off, and subsequently the filtrate was centrifuged at $9000 \mathrm{rpm}$ for $2 \mathrm{~min}$. The supernatant was vacuum evaporated to remove excess methanol. Then the concentrated extract was analyzed for determination of total phenolic content, ferulic acid and antioxidant activity.

\section{Extraction with Sodium Hydroxide}

In this method, $5 \mathrm{~g}$ of sugar beet pulp powder was placed in an Erlenmeyer flask attached to a condenser, and mixed with a $100 \mathrm{ml} \mathrm{NaOH} 0.5$ 
molL $\mathrm{L}^{-1}$ solution. It was heated up to $60^{\circ} \mathrm{C}$ for 2 , 6 and $12 \mathrm{~h}$ and then cooled down to $20^{\circ} \mathrm{C}$. Once the extraction process was completed, $\mathrm{pH}$ was reduced to 2.0, so that the hemicellulose would precipitate. The final mixtures were filtered off, and subsequently $150 \mathrm{~mL}$ ethyl acetate was added to the filtrates in a $250 \mathrm{ml}$ baffled Erlenmeyer flask and was shaken in vortex (100 rpm) at room temperature for 15 min to carry out a liquid-liquid extraction. The supernatant was separated and was placed in vacuum evaporator to remove excess solvent. All the treatments were conducted in triplicate and extracts were characterized through the determination of total phenolic compounds, ferulic acid and antioxidant activity.

It should be noted that all of the hydrolysates were held under nitrogen gas in a $250 \mathrm{ml}$ flask covered with aluminum foil and kept in a dark place in order to avoid phenolic compounds oxidation and cis-trans isomerization.

\section{Determination of Total Phenolics Content}

The total phenolics content of extracts was determined in accordance with a protocol described by Turkmen, and Velioglu [9]. $1 \mathrm{ml}$ of each sample was mixed with $5 \mathrm{ml}$ of FolinCiocalteu reagent (10\% in distilled water) in a test tube. After $5 \mathrm{~min}, 4 \mathrm{ml}$ of sodium carbonate (7.5\% in distilled water) were added to each tube, the test tubes were cap-screwed and vortexed. Mixtures were kept in dark at ambient conditions for $2 \mathrm{~h}$ to complete the reaction. The absorbance was measured at $765 \mathrm{~nm}$ with a UVvis spectrophotometer. Gallic acid was used as standard and the analyses were done in triplicate. The results were expressed as mg gallic acid $(\mathrm{GAE}) / \mathrm{g}$ sugar beet pulp extract.

\section{Measurement of Antioxidant Capacity of Sugar Beet Pulp Extracts}

Antioxidant capacity of methanolic extract of sugar beet pulp was performed immediately by ABTS method. The method used was the ABTS (radical cation) decolourisation assay [10]. The radical cation was prepared by mixing $7 \mathrm{mM}$ of ABTS stock solution with $2.45 \mathrm{mM}$ potassium persulfate $(1 / 1, v / v)$ and leaving the mixture for 4-16 $\mathrm{h}$ until the reaction was complete and the absorbance was stable. The ABTS•+ solution was diluted with ethanol to an absorbance of $0.700 \pm$ 0.05 at $734 \mathrm{~nm}$ for measurement. The photometric assay was conducted on $0.9 \mathrm{ml}$ of ABTS•+ solution and $0.1 \mathrm{ml}$ of tested sample and mixed for $45 \mathrm{sec}$; measurements were tacken immediately at $734 \mathrm{~nm}$ after $15 \mathrm{~min}$. The antioxidant activity of the tested sample was calculated by determining the decrease in absorbance by using the following equation:

$$
E=\left(\left(A_{c}-A_{t}\right) / A\right) 100
$$

Where At and Ac are the respective absorbance of tested sample and ABTS•+ was expressed as $\mu \mathrm{mol}$. Trolox chosen as standard antioxidant and the standard reference curve was constructed by plotting \% inhibition value against Trolox concentration between 10 and $600 \mu \mathrm{M}$. Antioxidant activity measurement, expressed as Trolox equivalent antioxidant capacity (TEAC). Each sample was measured in triplicate. Mean and standard deviation $(n=3)$ were calculated.

\section{HPLC Analysis for Ferulic Acid Determination}

The extracts from different extraction methods (methanolic, alkali extract) were passed through $0.22 \mu \mathrm{m}$ PTFE micro filters and $10 \mu$ l of the filtrates were injected into the HPLC system coupled online with a UV/Vis Agilent Technologies detector. The flow rate was adjusted on $1.0 \mathrm{~mL} / \mathrm{min}$ and the oven temperature was $35^{\circ} \mathrm{C}$. The mobile phase consisted of methanol and water (1\% acetic acid) $(35: 65, v / v)$ and the detector was set at $320 \mathrm{~nm}$. All quantitative analyses were carried out using ferulic acid as an analytical standard.

An aliquot of $10 \mu \mathrm{L}$ solution for each calibration standard solution was injected for HPLC analysis. The calibration curve was constructed by plotting the peak areas of the analyte against the concentration of ferulic acid.

\section{Statistical Analysis}

Analysis of variance (ANOVA) followed by Duncan's test was carried out to test for differences between extract (methanol and alkaline hydrolysis) in the statistical program SPSS ver. 15.0. Significance of differences was defined at the $5 \%$ level $(p<0.05)$. 
Table1. Total phenolic contents of different sugar beet pulp extracts.

\begin{tabular}{lcc}
\hline Methods & Reaction time $(\mathbf{h})$ & Total phenolic content (mg GAE/100 g db*) \\
\hline Methanolic extract & 2 & $128.19 \pm 3.25^{\mathrm{f}}$ \\
\hline Methanolic extract & 6 & $254.71 \pm 11.43^{\mathrm{d}}$ \\
\hline Methanolic extract & 12 & $183.11 \pm 10.98^{\mathrm{e}}$ \\
\hline Sodium hydroxide $\left(0.5 \mathrm{~m} \mathrm{molL}^{-1}\right)$ & 2 & $645.31 \pm 13.98^{\mathrm{c}}$ \\
\hline Sodium hydroxide $\left(0.5 \mathrm{~m} \mathrm{molL}^{-1}\right)$ & 6 & $893.24 \pm 21.87^{\mathrm{a}^{* *}}$ \\
\hline Sodium hydroxide $\left(0.5 \mathrm{~m} \mathrm{molL}^{-1}\right)$ & 12 & $761.43 \pm 14.67^{\mathrm{ab}}$ \\
\hline
\end{tabular}

*GAE: Gallic acid equivalent; db: dry base

**Each value is the mean of three replicates \pm standard deviation. The values in each column with the same superscript letter are not significantly different $(P<0.05)$.

\section{RESULTS AND DISCUSSION}

\section{Total phenolic contents (TPC)}

The total phenolics content of extracts was determined in accordance with Folin-Ciocalteu reagent method. Significant differences were found in TPC among different extracts and alkaline extracts contained higher amounts of polyphenols than methanolic extract. The average of total phenolics content of methanolic and alkaline extract were 188.67 and $766.66 \mathrm{mg}$ $\mathrm{GAE} / 100 \mathrm{~g} \mathrm{db}$, respectively.

Content of phenolics compounds in sugar beet pulp extract are exhibited in Table 1. Table 1 also summarized that alkaline extract have the highest total phenolic $(P<0.01)(893.24 \pm 21.87 \mathrm{mg} \mathrm{GAE} / \mathrm{g}$ dry extract). The results showed that alkaline treatment led to retained higher phenolics, which might be due to an alkaline hydrolysis breaks the ester bond linking phenolic acids to the cell wall and thus is an effective way to release phenolic compounds from polysaccharides. It is clear that chemical processes are more efficient to extract phenolic compounds by hydrolyzing the covalent esteric bond [5].

In the cell wall structure of sugar beet pulp, phenolic compounds such as ferulic and cumaric acids were etherified to lignin and arabinoxylans and forms an alkali-labile cross-link between these two cell wall polymers [11]. Such relatively higher content of alkali-labile cross-linkages within the lignin network or between lignin and polysaccharides might explain the fast and easy solubilisation of both phenolic acids by alkaline treatments Hasyierah [12]. Phenolic acids such as benzoic and cinnamic acids could not be effectively extracted with pure organic solvents, so mixtures of alcohol-water or alcohol-alkali are recommended. Our results are in agreement with the published results $[13,14]$.

\section{Antioxidant Capacity}

Antioxidant capacity of methanolic extract of sugar beet pulp was performed by ABTS method. Antioxidant capacity results expressed as $\mu \mathrm{mol}$ of Trolox equivalents per milligram of samples. The ABTS cation radical (ABTS•+) which absorbs at $734 \mathrm{~nm}$ (giving a bluish-green colour) is formed by the loss of an electron by the nitrogen atom of ABTS [2,2'-azino-bis(3-ethylbenzthiazoline-6sulphonic acid)] [15].

Antioxidant capacity for methanolic and alkaline extracts were shown in Table 2. According to results Significant differences were found at a significance level of $p<0.05$ between all extracts. Correlation coefficient showed that total phenolic content was responsible for antiradical efficiency in sugar beet pulp extracts. The antioxidant and total phenolic content levels are also positively and significantly correlated our results strongly suggest sugar beet pulp extracts can be promising sources of potential antioxidants that can be used as additive in food industry.

Among various fractions of sugar beet pulp extract, extraction with Sodium hydroxide $(0.5 \mathrm{~m}$ molL $\left.{ }^{-1}\right)$ in $6 \mathrm{~h}$ reaction time possessed the highest ABTS radical scavenging activity $(75.5 \pm 6.3 \mu \mathrm{g} /$ $\mathrm{ml}$ ), while methanol extract showed the lowest ABTS radical scavenging activity $(43.1 \pm 5.1 \mu \mathrm{g} /$ 
Table 2. Antioxidant activity of different sugar beet pulp extracts.

\begin{tabular}{lcc}
\hline Methods & Reaction time $(h)$ & $\begin{array}{c}\text { Antioxidant activity } \\
\text { ( } \mu \text { mol of Trolox equivalents) }\end{array}$ \\
\hline Methanolic extract & 2 & $43.1 \pm 5.1$ \\
\hline Methanolic extract & 6 & $52.4 \pm 2.7$ \\
\hline Methanolic extract & 12 & $47.6 \pm 4.1$ \\
\hline Sodium hydroxide $\left(0.5 \mathrm{~m} \mathrm{molL}^{-1}\right)$ & 2 & $64.1 \pm 4.2$ \\
\hline Sodium hydroxide $\left(0.5 \mathrm{~m} \mathrm{molL}^{-1}\right)$ & 6 & $75.5 \pm 6.3$ \\
\hline Sodium hydroxide $\left(0.5 \mathrm{~m} \mathrm{molL}^{-1}\right)$ & 12 & $70.3 \pm 3.2$
\end{tabular}

*Each value is the mean of three replicates \pm standard deviation. The values in each column with the same superscript letter are not significantly different $(P<0.05)$.

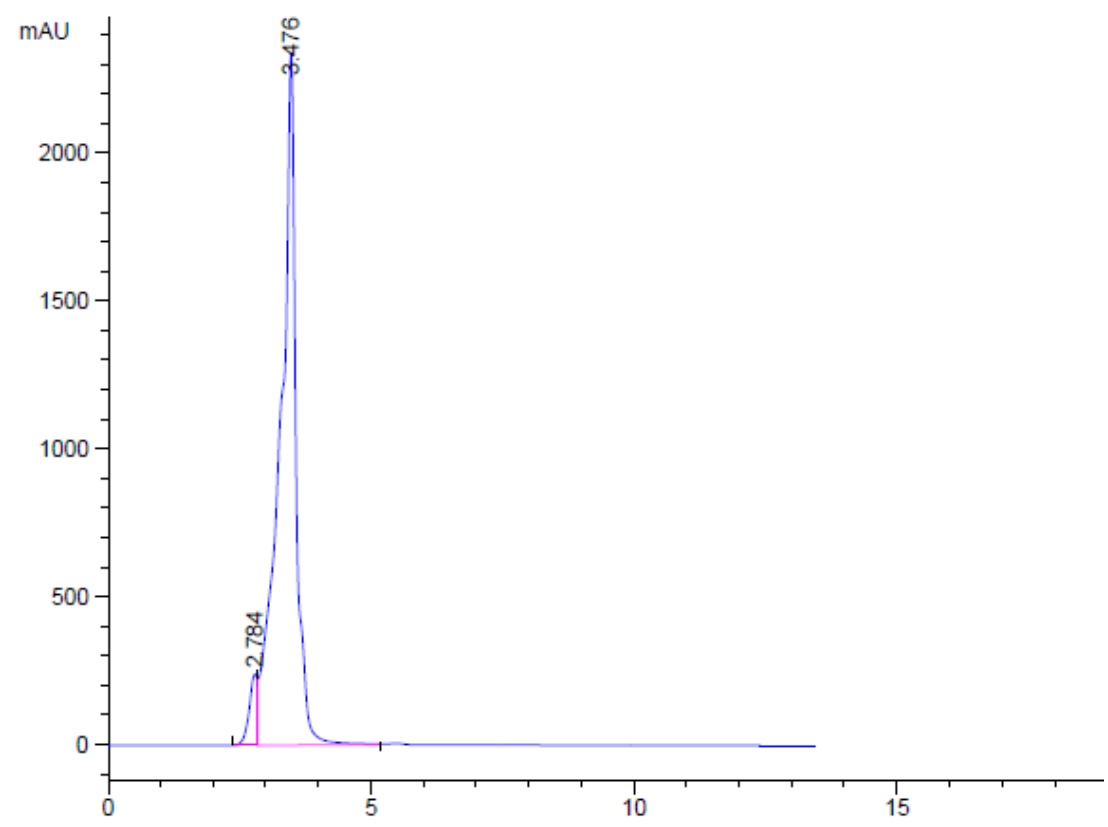

Figure 1. HPLC chromatogram of ferulic acid in C18 reverse phase chromatography at $320 \mathrm{~nm}$; a) standard; b) alkali treated sugar beet pulp extract (peak of ferulic acid $=3.4 \mathrm{~min}$ ).

$\mathrm{ml})$. Significant and positive correlation of TPCs and ABTS antioxidant capacity was obtained for various fractions $\left(P<0.05, r^{2}=0.8213\right)$.

\section{HPLC Analysis and Ferulic Acid Determination}

Ferulic acid was identified in the HPLC chromatogram of sugar beet pulp extracts. The HPLC chromatograms of hydrolyzed extract are shown in Figure 1. Intense peaks eluted at 3.47 min indicated ferulic acid as a major phenolic component of hydrolyzed extracts.

Results indicated that the concentration of ferulic acid in methanolic extract was much lower than that in the alkaline hydrolysates (Table 1). There were significant difference between the results for each specifications ( $p<0.05$ ) (Table 3 ). The ferulic acid concentration in the solvent and alkaline liquor varied according to extraction time and concentration and for methanol solvent treatments there were no significant difference between the results for each time $(p<0.05)$.

Ferulic and p-cumaric acid can be linked to lignin and/or polysaccharides through ester or ether bonds in cell walls. Alkaline hydrolysis breaks the ester bond linking phenolic acids to the cell wall and thus is an effective way to release phenolic compounds from polysaccharides. 
Table 3. Ferulic acid concentration of different sugar beet pulp extracts.

\begin{tabular}{lcc}
\hline \multicolumn{1}{c}{ Methods } & Reaction time $(\mathrm{h})$ & Ferulic Acid Concentration \\
\hline Methanolic extract & 2 & $12.15 \pm 0.14^{\mathrm{a}}$ \\
\hline Methanolic extract & 6 & $18.45 \pm 0.43^{\mathrm{a}}$ \\
\hline Methanolic extract & 12 & $27.5 \pm 1.28^{\mathrm{a}}$ \\
\hline Sodium hydroxide $\left(0.5 \mathrm{~m} \mathrm{molL}^{-1}\right)$ & 2 & $120.1 \pm 2.17^{\mathrm{c}}$ \\
\hline Sodium hydroxide $\left(0.5 \mathrm{~m} \mathrm{molL}^{-1}\right)$ & 6 & $234.7 \pm 1.38^{\mathrm{f}}$ \\
\hline Sodium hydroxide $\left(0.5 \mathrm{~m} \mathrm{molL}^{-1}\right)$ & 12 & $456.3 \pm 2.94^{\mathrm{h}}$ \\
\hline
\end{tabular}

*Each value is the mean of three replicates \pm standard deviation. The values in each column with the same superscript letter are not significantly different $(P<0.05)$

In comparison between solvents the amount of ferulic acid in alkaline extract was higher than that in methanolic extract. This was probably due to the relative polarity and the increase in effective swelling of the plant by water and alkali, which helped increase the surface area for solute-solvent contact [16]. Also the results demonstrated that coniferyl ferulate was readily hydrolyzed into ferulic acid in a weak basic solvent, and hence a large amount of ferulic acid could be determined [7].

According to the obtained results, the main key factors affecting the releasing rate of phenolic compounds are alkali concentration and hydrolysis duration. The same result has previously been reported for the effect of these factors on the yield of extraction from the other sources such as paddy straw, sugar cane baggas and agricultural wastes [4,12-15].

\section{CONCLUSION}

Methanolic and alkaline extraction procedures were applied to extraction of total phenolic compounds and ferulic acid from sugar beet pulp. Significant differences were found in TPC among different extracts and alkaline extracts contained higher amounts of polyphenols than methanolic extract. Antioxidant capacity for extracts was shown that the significant differences were found at a level of $p<0.05$ between all extracts. The antioxidant and total phenolic content levels are also positively and significantly correlated our results strongly suggest sugar beet pulp extracts can be promising sources of potential antioxidants that can be used as additive in food industry.
Also results showed that alkaline hydrolysis of sugar beet pulp released high amounts of ferulic acid, which allows to be used as antioxidants in foods.

\section{References}

1. E. Middleton, C. Kandaswami, T.C. Theoharides, The effects of plant flavonoids on mammalian cells: Implications for inflammation, heart disease and cancer. Pharmacol Rev, 52 (2000) 673.

2. K. Alpinar, M. Ozyurek, U. Kolak, K. Guclu, C. Aras, M. Altun, S.E. Celik, K.I. Berker, B. Bektasoglu, R. Apak, Antioxidant Capacities of Some Food Plants Wildly Grown in Ayvalik of Turkey". Food. Sci. Tech. Res., 15 (2009) 59.

3. A. Eghdami, F.Sadeghi, Determination of total phenolic and flavonoids contents in methanolic and aqueous extract of Achillea Millefolium. Org. Chem. J., 2 (2010) 81

4. A. Tilay, M. Bule, J. Kishenkumar, U. Annapure, preparation of ferulic acid from agricultural wastes: its improved extraction and purification. J. Agric. Food. Chem., 56 (2008) 7644

5. S.B. Ghatak, S.J. Panchal, Ferulic acid-an insight into its current research and future prospects. Trends in Food Science \& Technology, In Press, Accepted Manuscript, Available online 13 November (2010).

6. H.Z. Zhao, M.H. Moghadasian, Chemistry, natural sources, dietary intake and pharmacokinetic properties of ferulic acid: A review, Food Chem., 109 (2008) 691.

7. G.H. Lu, K. Chan, K. Leung, C.L. Chan, Z.H. Zhao, Z.H. Jiang, Assay of free ferulic acid and total ferulic acid for quality assessment of Angelica sinensis. J. Chromatogr. A, 1068 ( 2005) 209.

8. M. Bunzel, J. Ralph, C. Funk, H. Steinhart, Isolation and identification of a ferulic acid dehydrotrimer from saponified maize bran insoluble fiber. Eur. Food. Res. Technol., 217 (2003) 128.

9. N. Turkmen, F. Sari, Y.S. Velioglu, The effect of cooking methods on total phenolics and antioxidant activity of selected green vegetables. Food. Chem., 93 (2005) 713 
10. M.E. Alanon, L. Castro-Vazquez, M.C. Diaz-Maroto M.H. Gordon, M.S. Pérez-Coello, A study of the antioxidant capacity of oak wood used in wine ageing and the correlation with polyphenol composition. Food. Chem., 128 (2011) 997.

11. P. Torre, B. Aliakbarian, B. Rivas, J.M. Dominguez, A.A. Converti, Release of ferulic acid from corn cobs by alkaline hydrolysis. Biochem. Eng. J., 40 (2008) 500.

12. M.S. Noor Hasyierah, M.D. Mohamed Zulkali, A Dachyar, A. Muhammad Syarhabil, K.I. Ku Syahidah, Optimization of alkaline hydrolysis of paddy straw for ferulic acid extraction. Ind. Crop. Pro., 34 (2011) 1635.

13. C.D. Stalikas, Extraction, separation and detection methods for phenolic acids and flavonoids. J. Sep. Sci., 30 (2007) 3268.
14. D.S. Oufnac, Xu, Z. Sun, T. Sabliov, C. Prinyawiwatkul, W. Godber, J.S. Extraction of antioxidants from wheat bran using conventional solvent and microwaveassisted methods. Cereal. Chem., 84 (2007) 125-129.

15. A.M. Pisoschi, and G.P. Negulescu, Methods for total antioxidant activity determination: a review. Biochem. Anal. Biochem., 1 (2011) 1.

16. Y. Sun, W. Wenhua Wang, Ultrasonic extraction of ferulic acid from ligusticum chuanxiong. J. Chin.Inst. Chem. Eng., 39 (2008) 653.

17. F. Xu, R.C. Sun, J.X. Sun, C.F. Liu, B.H. Heb, J.S. Fan, Determination of cell wall ferulic and p-coumaric acids in sugarcane bagasse, Anal. Chem. Acta., 552 (2005) 207. 
